\title{
Analysis of commercial bank customer's financial consumer behavior based on brand factor
}

\author{
Yi Yang \\ Department of business \\ Guilin University of Electronic Technology \\ Guilin, Guangxi, China \\ 463760070@qq.com
}

\author{
Pengfei Wang \\ Department of business \\ Guilin University of Electronic Technology \\ Guilin, Guangxi, China \\ 790984760@qq.com
}

\begin{abstract}
Our country unceasingly intensifying competition between the banking sector, Bank is taking measures, in order to seek the way of business under this pattern. Therefore, this paper started from brand factors to analyze consumer behavior, in order to enhance the competitive advantage of commercial bank. This paper is based on the brand, to an objective and comprehensive analysis of the commercial bank customer's financial consumer behavior. Firstly, put forward the influencing factors of customer's financial consumer behavior, the factors including age and gender, psychological and cultural, brand and so on. Secondly, commercial banks to establish a brand image strategy are proposed, such as to grasp the market positioning, to achieve differentiation of brand image; rational use of advertising strategy; focus on maintaining customer loyalty to the brand. The innovation of this paper is an analysis of the impact of brand factors on customer's financial consumer behavior in commercial banks. Therefore, the conclusions can be applied to some commercial banks in some degree.
\end{abstract}

Keywords-Commercial bank; Financial consumer behavior; Brand factor; suggestions

\section{INTRODUCTION}

With the development of science and technology and economic globalization, the openness of China's financial industry is constantly improving. The financial industry shows a momentum of vigorous development, especially the development of the banking industry in China, and there are a number of bank assets and profit at the forefront of the world. In this fast developing, the brand factors played an important role on the development of the banking. In the global banking in 2016 released by the British banker magazine Bank around world brand 500 strong, we can see that the global banking industry's overall brand value growth is relatively weak. But Chinese banking brand value increase rapidly, the world's top five brands bank has three from China, respectively is ranked second in the industrial and Commercial Bank of China; ranked third in the China Construction Bank and row in fourth place in the Agricultural Bank of China. In brand value rose the fastest big ten banks, there are eight from China, the two banks increase compared with 2015. In fact, in addition to the Banks, each bank of China within the global top 500 brand value is improved. Obviously Chinese banking brand to achieve a qualitative leap. Therefore, in addition to domestic commercial

This work is supported by the national natural science fund project: research on consumers' brand perception differences about "domestic" and

"import" brand and influence mechanism. The project number is 71262015 . banks in developing basic business areas, they are all committed to brand investment.

As early as the end of 1990s, some marketing scholars put forward the relationship between brand and consumer is similar to the partnership. For example, Palmer is mainly that the brand is the bond of connecting consumers and enterprises[1]. As the degree of attention to the brand of continuous improvement, scholars know that brand influence on the consumers should not be overlooked. Fred Selnes believes that brand trust has always been a precursor of attitude loyalty and behavior loyalty are the most important[2]. That is to say, the commercial bank customer trust to the brand led directly to consumer behavior of financial customers. Storbacka, Strandvik Gronoross and points out that customer satisfaction is defined as the customer in the process of relationship with service enterprise, based on himself in all of the cognitive and affective evaluation service experience in the plot[3]. For the banking sector, the essence of which is to provide a satisfactory service to bank customers and let the bank customers in its financial consumer feel the quality of service. Goodyear describes the brand with consumer relationship roles in the development stage[4]. She insists that Market evolution can be understood as consumer behavior continues, and the continuation of reflects the marketing personnel and consumers of the extent of the dialogue. In different stages, brand played different roles and had different meanings for consumers. Initially, the brand is only a measure of product quality of reference. With the marketing personnel in the brand add an emotional component, brand development of the personality, when intimate relationship is set up, the brand has become the idol. And then, consumers have become very vulnerable to the impact of the company's marketing activities. Finally, the brand has become synonymous with corporate policy; in recognition of the social culture assume more responsibility.

In the financial system of our country, the position of the bank is very important, especially the commercial bank. At present, the five state-owned commercial banks have occupied more than $50 \%$ of the entire market share. Other joint-stock commercial Bank, by contrast, have made great development, part of the financial (holding) group has gradually to the mixed management way. As a special corporation working on currency, whose brand factors play an important role in their 
fields. A brand reflects a kind of responsibility and culture, a kind of social responsibility and social identity of enterprise deep culture connotation. Commercial bank brands include commercial Bank themselves as the brand of an enterprise and its brand for the overwhelming majority of customers with product. It, through the brand, shows products and culture for customers, so as to stimulate consumer behavior. Therefore, for commercial banks, based on how the brand factors improve customers in financial consumer behavior is particularly important.

\section{BRAND BENEFIT}

With the progress of human society, the development of social civilization, in the past, companies rely on products to enhance the competitiveness of enterprises, to obtain a larger market share, which times has passed. In modern times, due to the progress of the era and the development of science and technology, the income level of consumers is also constantly improving, consumer need not only material satisfaction, but also for spiritual demand performance is more outstanding. Brand from the original is a just product marking, and now has become a consumer's personality and characteristics. Commercial bank's product itself is a kind of service, so the commercial bank financial brand should also be a kind of service brand. Brand for the benefits of commercial Bank can also not be ignored. As such, commercial Bank should establish, maintain the brand image and generate more brand effect. To China Construction Bank as an example, a few days ago, the British bankers' magazine announced the 2016 global banking brand value top 500 lists, Construction Bank ranked third in the world, compared to last year promotion a, brand value significantly enhances $\$ 90$ billion. At the same time, under the drive of construction bank brand, China construction bank launched a variety of financial products such as QDII. Unquestionably, it is because of China construction bank brand benefit brought by the powerful competitiveness.

\section{THE INFLUENCING FACTORS OF COMMERCIAL BANK CUSTOMER'S FINANCIAL CONSUMER BEHAVIOR}

\section{A. Ages and Sex factors}

In different age stages, consumers have different opinions on products. For instance, for older people, it is much easier to go to the bank to deposit money, but buy less of its financial products, in contrast, relatively small; it will choose to buy more financial products. Different sex has a great effect on the impact of consumer behavior. For example when men shopping, they pay attention to the function, quality, while women pay more attention to beauty, fashion, easy to use.

\section{B. Cultural and Psychological factors}

For everyone, as a result of the growing environment and the different education, therefore, financial consumption behavior will be different.

\section{Family social status}

Family social status in difference has a certain impact the consumer behavior of the family and members, including occupation, education, income, family reputation.

\section{Family life cycle}

Family life cycle is to point to starting a family, then to parents after death or elderly parents and adult children, into the children families for the entire period. What's more at different stages of life, family members of the age, the number of members, the level of income and wealth, to respective characteristics and mutual relations, consumer behavior will affect the family and its members.

\section{E. Service factor}

Consumers in the pursuit of personalized services and products, hope that they can be special treatment, so that they can be different, in order to show their personality.

\section{F. Brand factor}

Brand is the buyer or potential buyer have an impression or emotional, describing an organization doing business or consuming a product or service, relating experience[5]. Brand in many factors which affect the purchase behavior is very large, it not only can bring huge profits for the enterprise, but also for the enterprise to create more value added.

\section{THE INFLUENCE OF BRAND FACTORS THE CONSUMER BEHAVIOR OF COMMERCIAL BANK CUSTOMERS}

\section{A. The Appearance Design of Products}

The brand represents an enterprise, which can present the characteristic of the enterprise product. The essence of commercial banks is a service enterprise, which extends from the first simple deposit and loan business to the current financial products business, and the brand is becoming more and more important to commercial banks. With the competition between commercial banks, brand differentiation is becoming increasingly important, but the product blindly follows the trend, there is no unique personality, as a result, it is bound to be eliminated by the market. Different types of bank clients demand financial products will be different, and gradually form a kind of product preferences. In customer purchase experience, brand features, style and other basic factors will consist of the customer for the whole image of the brand. Therefore, the difference of the product design is able to strengthen the customer's brand preferences, and then affect the customer's loyalty to the brand.

\section{B. Brand Culture}

With the progress of the times, the customers of commercial Bank become more and more pay attention to the brand of enterprise culture. Enterprise culture construction, it is to the bank in the process of the different stages of development and formation of integrating different values, carefully refined suitable for their own development of a series of value ideas[6]. Brand culture is the heart of life, the use of consumers on the appreciation and recognition of traditional 
culture, Chinese traditional cultural symbols applied to financial products, so as to make the consumer get beyond the financial products of commercial banks using the value of psychological feelings. Commercial banks should focus on refining their management theory and corporate culture; enhance the brand connotation, the formation of brand culture, highlighting the unique personality. The brand represents the culture of an enterprise, which shows the connotation of the culture will become making an important choice for their customers. Brand culture can enhance the customer's identity and trust in the product and business behavior of commercial banks, so as to enhance the competitiveness of the banking industry.

\section{Service Level}

Banks are special enterprises, running special goods-money and capital[7]. Therefore, it is very important to the service level for commercial banks. Service is a kind of soft quality, for commercial bank customers, and it presents a kind of warm, appropriate, comfortable service. Customers pay attention to their own feelings; the brand's perception of the heart will often affect the customer's choice. Hence, the high quality service level will increase customer satisfaction and loyalty. Brand service to be good at finding the customer's emotional needs, looking for customer demand, based on different demands, improve service levels, guide consumption, establish and maintain customer loyalty to the brand.

\section{COMMERCIAL BANKS TO SET UP THE BRAND IMAGE STRATEGY RECOMMENDATIONS}

Bank customers for brand awareness, the most important are to depend on the brand image. In terms of the Banks, the brand is the intangible asset of an enterprise, can bring the interests of the excess, which is a kind of added value, can produce greater profits for the bank. From the point of view of commercial bank customers, a good brand is an important basis for their choice of investment or financial management. Therefore, to establish a good brand image and strive for and to maintain customers resources are the key to the commercial Bank win in the future competition.

\section{A. Grasp the market positioning, to achieve differentiation of brand image}

Commercial banks should be based on a clear customer financial consumer demand, accurate grasp of market positioning, combined with the characteristics of the bank itself, to establish a brand image. Especially for high-end customers, targeted to implement differentiation marketing strategy, scientific and reasonable brand promotion, publicity for highend customers. Some of the leading banks have already begun with large customers to establish some tailored consultant relations so as to enhance market penetration. According to the customer's property status, the bank will provide reasonable financial solutions for customers. In the past, the bank will usually find customers according to the financing plan.

\section{B. On the basis of the corporate image and product image, brand image planning}

The construction of brand image should be consistent with the image of the enterprise. At the same time, we should set up its own brand building department; in the process of brand building should actively seek the support of senior leadership, enhancing understanding of the senior leadership of the importance of brand image building and in actual operation can get a support of the various departments and enterprises. The product is the carrier of the brand image. In general, the traditional banking industry classification includes assets, liabilities and intermediary business, local currency and foreign exchange, retail business. However, for customers, they are fuzzy. In today's increasing degree of product homogeneity, to create a brand product and brand service system, and to provide customers with satisfactory products and services are an important weapon for enterprises to create a good brand image. Because of the service level, personnel quality, development and innovation ability of factors of the differences, although bank products is homogeneous, bank products may exhibit different values. At the same time, in the product development and innovation, because banks' development capabilities and customer needs are different, they developed the product function will always be different. In a word, brand positioning must be prominent. And the character of brand positioning must be that consumers can feel. If consumers do not understand the brand message, then the position is a failure, so the positioning of brand and consumer imagination, linked to feelings.

\section{Rational use of advertising strategy}

Advertising is the best weapon to promote the brand. Rational use of advertising campaign is conducive to improving the bank brand image recognition; what's more, it maintains the brand image. Eye-catching signs and bank marks in service terminal will leave deep impression to consumers. In recent years, the commercial bank continuously intensifies on advertising delivery. First of all, product coverage is becoming widely. In order to improve the accuracy of advertising, it should be a comprehensive understanding of the professional product propaganda demand, actively communicate with media contact. Secondly, accurately grasp the advertising time. Make full use of the festive opportunity, actively carries out product advertising in traditional media and electronic media coverage, effectively boosting the full line of business development. Finally, advertising targeted, banks should pay attention to the focus of the business area.

In a word, advertising should be simple and clear, and must put up the brand's value proposition and commitment. Only in this way can it achieve unexpected results.

\section{Focus on maintaining customer loyalty to the brand}

Brand loyalty can bring huge profits for the bank, which can gain the advantage for the bank in the future competition. Therefore, it is essential to establish and maintain the brand loyalty of the bank. High brand loyalty can improve the brand image of commercial banks. Commercial banks can provide differentiated marketing to different customers through return 
visit regularly and quality service, so as to maintain the customer's brand loyalty to the bank.

\section{CONCLUSION}

In today's society, with the constant pursuit of life taste, they are more and more valued brand personality. Therefore, how to make the business of commercial banks to become personalized is particularly important. Brand image is crucial for an enterprise, especially as a special enterprise, carrying on money. Accurately grasp the impact of brand factors on financial consumer behavior of commercial customers, not only to create a considerable profit for the enterprise, but also to enable enterprises to compete in the future stand out.

\section{REFERENCES}

[1] Palmer A J.Integrating brand development and relationship marketing[J]. Journal of Retailing and Consumer Services, 1996, 3(4): 251- 25.

[2] Aydin Serkan Ozer Gokhan. Online reviews do consumer use them: The analysis ofantecedents of customer loyalty in the Turkish mobile telecommunications market [J]. European Journal of Marketing. 2005. 39(7/8). 910-92.

[3] Storbacka, Strandvikd and Gronoross. Managing Customer Relationships for Profit: the Dynamics of Relationship Quality. International Journal of Service Industry Management. 1994. 5(5): 21-28

[4] Goodyear, Mary. Divided by a common language: Diversity and Deception in the world of Global Marketing, Journal of Market Research Society, vol. 38(Apr), Iss.2, pp. 105-122

[5] Liu chaoju, The enterprise culture and brand image research of commercial banks, J. Modern business, vol. 9, pp. 31, 2010.

[6] Del l. Hawkins, David L. Monthersbaugh, Consumer Behavior, twelfth ed, China Machine Press, Beijing, 2014.

[7] Ruan jiamei, Advanced cultural construction of brand leading agricultural bank, J. China Economist, vol. 2, pp. 276-277, 2014. 